University of Pennsylvania Carey Law School

Penn Law: Legal Scholarship Repository

Faculty Scholarship at Penn Law

1995

\title{
Union Effects on Nonunion Wages: Evidence from Panel Data on Industries and Cities
}

\author{
David Neumark \\ University of California - Irvine \\ Michael L. Wachter \\ University of Pennsylvania Carey Law School
}

Follow this and additional works at: https://scholarship.law.upenn.edu/faculty_scholarship

Part of the Benefits and Compensation Commons, Collective Bargaining Commons, Labor and Employment Law Commons, Labor Economics Commons, Law and Economics Commons, and the Unions Commons

\section{Repository Citation}

Neumark, David and Wachter, Michael L., "Union Effects on Nonunion Wages: Evidence from Panel Data on Industries and Cities" (1995). Faculty Scholarship at Penn Law. 1369.

https://scholarship.law.upenn.edu/faculty_scholarship/1369

This Article is brought to you for free and open access by Penn Law: Legal Scholarship Repository. It has been accepted for inclusion in Faculty Scholarship at Penn Law by an authorized administrator of Penn Law: Legal Scholarship Repository. For more information, please contact PennlawIR@law.upenn.edu. 


\title{
UNION EFFECTS ON NONUNION WAGES: EVIDENCE FROM PANEL DATA ON INDUSTRIES AND CITIES
}

\author{
DAVID NEUMARK and MICHAEL I.. WACHTER'
}

\begin{abstract}
The atuthors test for threat and crowding effects of unions on momunion wages at the industry and city levels, using panel data on the pereent organized and nonunion industry and citv wage differentials constructed from Current Population Surveys over the period 1979-89. At the industry level, increases in the percent organized were associated with decreases in the nonunion industry wage differentiat, suggesting that crowding effects were the predominant union effect on nonumion industry wage differentials. In contrast, at the city level increases in the percent organized were associated with increases in the nonunion city wage differential, suggesting that threat effects predominated. The authors also find evidence of negative cross-occupation union effeets on nonunion industry wage differentials, supporting their hypothesis that the industry-level results were partly driven by complementarity beween union and nonunion labor.
\end{abstract}

$\mathrm{T}$ he two prevailing models of the impact of unionization on the nonunion sector are the union threat model and the crowding or spillover model. The union threat model predicts that an increase in union strength, typically measured as the percentage of workers in the industry that are unionized, will cause nonunion employers to increase the wages they pay in order to forestall unionization. The crowding model focuses instead on the effects of spillovers from the union sector to wages in a market-clearing nonunion sector. Whereas the nonunion sector "acts like the union sector" in the threat model, the nonunion sector reacts competitively in the crowding model. Thus, for example, a higher percentage organized causes the nonunion supply curve to shift out, reducing the wages of nonunion workers; that is, the higher costs associated with higher wages in the union sector result in layoffs of some union workers, who, perhaps because of their industry-specific training, join the labor supply for nonunion firms in the same industry, putting downward pressure on wages in those lirms. Although the threat model is typically viewed as describ-

'David Neumark is Prolessor of Economicsat Michigan State University and a Facults Research Fellow of the NBER; Michael Wachter is the William B, Johnson Professor of Law and Economics and Director of the Institute of law and Ecouomics at the University of Pennsylvania. They thank Cus Fatucher for outstanding research assistance, Charles Brown. William Dickens, Christopher Hanes, Harry Holzer, Alan Krueger, David Levine, and Jacwoo Ryoo for helptul comments, and Diane Herz for providing data from the Displaced Workers Surveys. Research support was provided by the Instiutce lor Law and Economics, University of Pennsylvania. The data and programs used in this paper are watable from the authors upon request. 
ing a relationship between the union sector in an industry and the nonunion sector of the same industry, it has also been applied to the relationship between union and nonunion sectors within geographical regions, most notably cities.

Economists have long debated the relative importance of threat and crowding effects. Friedman argued that "any rise in the wage rate secured by unions for certain classes of workers would tend to lower the wage rates of other workers" (1951:21516). In contrast, frequently cited surveys of nonunion employers have found that wages in nonunion firms are strongly influenced by the desire to avoid unionization (Rees and Shultz 1970; Foulkes 1980; Conant 1959). The competing views are still reflected in modern labor economics and industrial relations texts. Reynolds et al. (1991) concluded that threat effects prevail, at least for primary sector workers: "Not only will the threat effect be important but there will be little spillover effect in primary labor markets, because the wage normally exceeds the level needed to clear the market" (p. 549). On the other hand, Ehrenberg and Smith concluded that the spillover effect appears to outweigh the threat effect (1989:566).

Early regression evidence suggests that threat effects predominate, leading to a positive relationship at the industry level between the percent organized and nonunion wages. More recent evidence based on estimated cross-sectional relationships between the percent organized (and other potential proxies for the strength of the union threat) and nomunion wages or wage differentials tends also to suggest that threat effects predominate. However, a critical limitation of the cross-sectional evidence for testing the relative importance of threat and crowding effects is that there may be unmeasured characteristics associated with heavily unionized industries or cities.

In this paper, we provide the first comprehensive test of the relative importance of union threat and crowding effects that exploits panel data to remove the influence of unmeasured characteristics associated with high nonunion wages, as well as the percent organized. The paper tests for threat and crowding effects in three contexts: within industries, within cities, and across occupations, within industries. The cross-occupation analysis tests a third hy. pothesis that we introduce to help explain the within-industry effects of unions on wages in the nonunion sector, namely that there are some complementarities between union and nomunion labor.

To control for unmeasured characteristics associated with both nonunion industry or city wage differentials and the percent organized, we use fixed industry and fixed city effects in the respective analyses. To the extent that the unmeasured characteristics are fixed over time, this procedure should remove the bias. The period we use for the study is $1973-89$, a particularly interesting period for testing union effects on the nonunion sector because of sharp changes in the percent organized over this period, especially in the goods-producing sector.

\section{Testing the Strength of Union Threat and Crowding Effects at the Industry Level}

\section{The Nonunion Industry Wage Differential Equation}

Testing for threat effects requires a variable that measures the magnitude of the union threat. The measure of union strength adopted in the literature is the percent organized (\%ORG), with a predicted positive coefficient in an equation explaining nonunion industry wage differentials $\left(w^{n u}\right)$. Rosen (1969) developed the argument regarding the percent organized in detail. First, the percent organized is likely to be positively related to the probability that a nonunion firm will become unionized. Arguably, this probability increases with the percent organized, although this is an empirical question.' Second, Marshall's

\footnotetext{
'For example, Rosen suggested that at high values of the percent organized, the probability of unionization may fall because the remaining nonunion firms are particularly resistant to unionization. Nonethe-
} 
laws suggest that a higher percent organized may lead unions to raise wages further above their competitive level, because the elasticity of demand for union labor is likely to be lower in absolute value when there are fewer substitution possibilities.

Whereas the nonunion sector icts like the union sector" in the threat molel, the central tenet of the crowding model is that the nomunion sector reacts competitively. At the industry level, workers industryspecific human capital causes those who are displaced from the union sector 6 shilt into the nonunion sector of the satme industry." Consequently, the standard view in the literature is that the response of $w^{\prime \prime \prime}$ to an increase in \%oRg is the reverse of that in the threat model (for example, Kahn 1979; Freeman and Medoff 1981; Holzer 1982). ${ }^{3}$

There are two explanations for the presumed negative effect of the percent organized on nonunion wages in the crowding model. The predominant view is that an increase in \%org acts as a proxy for higher union wages. Again, based on Marshall's laws, unions raise wages more when the percent organized is high, since there is less competition from the nonunion sec-

less, for two reasons it seems reasonable to expect a positive relationship between the percent erganized and noumion wage differentials in our data. if the threat model is correct. First, while the difficulty of unionizing may actually increase at very high Jevels of unionization, such a pattern hardly secus to characterize unionization rates in the United States in the simple period. Second, much of the individuat-level evidence on the union threat hypothesis confirms, at least to a limited extent, positive relationships between individuals' wages and the percent of their industry unionized.

-Supply shifts out in the nomunion sectoraslong as the elasticity of labor demand in the union sector outweighs the vacancy rate in the union sector. (See Mincer 1976 for a similar argument in the context of minimum wage effects.)

The existing literature suggests two reasons why unionization may not result in outward supply shifts in the nonunion sector. First, ander efficient bargaining, unionization results only in the reallocation of rents (see Brown and Ashenfelter 1986: Abowd 1989; Bronars et al. 1993). Second, some researchers argue that unionization might inctease: the productivity of union labor (Allen 1984; Brown and Medoft 1978; Clark 1980). tor. The high wages, in turn, catuse losses in the union sector, and the placed workers then crowd into the union sector, causing the nonumion. to decline. ${ }^{4}$

An alternative interpretation consi with the standard prediction is that cha in \%org reflect movements of firms c tablishments from onc sector whe the For example, if a heretofore nomunion becomes unionized, tire percent orgat rises. If the result is the establishmen union wage premium in the newly u ized firm, the firm responds by cu employment, hence shifting out supl the nonunion sector and reducing $u w^{\prime}$

Ourstrategy follows the recent liter: in first estimating nonunion industry differentials and then studying the $c$ minants of these differentials (Kruege

The downward wage pressure from the $\mathrm{sp}$ of workers from the union sector to the non sector is presumed to outweigh any positive $\mathrm{i}$ resulting from a shift in labor demand from the sector to competitor firms in the nonunion se

${ }^{5} \mathrm{Yet}$ another interpretation is that variat $\%$ org stems from labor demand shifts in the sector, that is, shifts of the labor demand rather than movements along it. In this $\mathrm{c}$ increase in the percent organized reflects in $\mathrm{L}$ shift in labor demand in the uniou sector. Asw leave the nonunion sector to find jobs in the sector, supply shifts inward in the nomurion resulting in an increase in the nonunion wage ential. We considered this interpretation in work (Neumark and Wachter 1993), but we fo the more traditional interpretation here.

In Neumark and Wachter (1993) we also , ered extending the usual framework by consi the within-industry union wage premium as a explanatory variable, with a predicted positive cient in the threat model (as in Dickens 1986 predicted negative effect in the crowding (Kahn and Morimune [1979] discussed a sim fect that can arise if high union wages draw not workers into unemployment quenes for unio raising nonunion wages.) However, implem tests with this variable is problematic, as it is $1:$ be negatively correlated with the nonuniot differential by construction, so in this paper strictattention to the percent organized. The paper considerably expands on our earlice pi analyzing city as well as industry nonunior differentials, and by examining nonunion is wage differentials within and across occupat test the complements model. 
Summers 1987; Dickens and Katz 1987a. 1987b; Keane 1993; Helwege 1992). "Nonunion industry wage differentials "refers to wage differences between nonumion workers in different indusuies that remain after controlling for individual-level characteristics (and sometimes firm-level characteristics) that theory suggests oughit to be related to workers marginal products. In cross-sectional studies, this wo-step approach has been defended by Dickens and Katz (1987a) as a means of avoiding biases in both coefficicnt estimates and standard errors arising from ingregation (Mouton 1990; Dickens and Ross 1984). Certainly, because the identifying information comes from industry-level shifts in variables such as the percent organized, there is no added information in the individual-level data. Based on these considerations, we think our results are most informative if we use the two-stage approach, which asks how union strength variables explain these nonunion industry wage differentials that others have documented.

We therefore estimate the following industry-level equation to test the relative strength of union threat and crowding effects on nonunion industry wage differentials:

$$
w^{m u}=\alpha+\%_{0} \text { ORG; } \beta+I \gamma+\varepsilon_{i t} .
$$

The $I$ are a set of industry dummy variables, included to capture fixed industry characteristics that may be associated with both nonunion industry wage differentials and the independent variables. Fixed year effects are also included to capture any

"Earlier research (Cullen 1956) also focused on industry-level characteristics, because individual-level data were unavailable.

An alteruative method of studying threateffects is to examine directly the factors associated with the risk of a nomunion firm being organized, and the firm's reaction to this risk (Freeman and Klciner 1988).

${ }^{7}$ Krueger and Summers (1988) argued that such nonunion industrv wage differentials or premia pose a challenge to purely competitive models of waye determination, and offered an array of evidence sug. gesting that these differentials cannot be explained by competitive models. common year cffects. ${ }^{8}$ For \%orc to identify union threat or crowding effects, the omitted characteristics that are correlated with the percent organized must be fixed over time; this, of course, is our maintained assumption, although we also analyze the sensitivity of the results to the inclusion of some rime-tarying industry-specific control variables. An equation paralleling this one is used to explore intra-city nonunion wage variation, as well as intra-industry effects across necupations.

\section{Past Research on Union Effects on Nonunion Wages at the Industry Level}

Early regression evidence reported by Rosen (1969) showed a positive relationship at the industry level between the percent organized and wages, and thus suggested that threat effects predominate. Rosen's data did not distinguish wages of union and nonunion workers. Since that study, a number of papers have reported estimates of cross-sectional regressions of nonunion wages on the percent organized in the worker's industry, and other control variables (see, for example, Freeman and Medoff 1981; Podgursky 1986; Hirsch and Neufeld 1987). This research tends to find evidence consistent with a positive association between the percent organized and nonunion wages, although often only for certain types of workers or firms. For example, Podgursky (1986) found a positive relationship at the industry level, but only in large firms, and Freeman and Medoff (1981) found the relationship between the percent organized among production workers in the industry and nonunion wages to be positive, but only weakly significant. The evidence in Hirsch and Neufeld (1987) points more consistently toward the threat model at the industry level. ${ }^{9}$

The fixed year effects also eliminate any effects of the choice of the omitted industry in the regression from which the nonunion industry wage differentials are estimated (sec footnote 12).

Krueger and Summers (1988) argued against the threat model based on evidence that the nonunion inclustry wage structure in the South has a correlation of 0.6 with that in the rest of the country, despite the 
Dickens and Katz (1987a, 1987b) provided a more detailed analvsis of the union threat model. They found that the sign of the \%org variable in regressions for $w " \omega^{\prime \prime \prime}$ is generally positive as alternative industry characteristics are included or omitted, atthough it is sometimes negative (for nranufacturing workers) and often statistically insignificant. However, some of the other correlates of nomunion industry watge ditferentials also appear to support the threat model, particularly the positive coeflicient on profitability, which supports the hypothesis that the higher the potential rents, the higher the wage (Dickens 1986). Dickens and Katz (1987a) concluded that "existing studies generally find that industry union density is positively related to the earnings of ... nonunion workers" (p. 63). They recognized, however, that other theories of non-market-clearing wages (for example, Akerlof 1982; Lindbeck and Snower 1988) also predict a positive relationship between rents and wages. Also, Dickens and Kats. noted that it is difficult to sort out the independent influences of the large number of industry characteristics that they considered, since industry characteristics are highly correlated.

A critical limitation of the cross-sectional evidence for testing the relative importance of threat and crowding effects, which we address in this paper, is that there may be unmeasured industry characteristics associated with heavily unionized industries. For example, Krueger and Summers (1987) argued that the historical cvidence suggests that high-wage industries were already paying high wages before the advent of wide-scale unionization in manufacturing. They noted that the Big Three auto makers in the United States were wage leaders prior to becoming unionized. In addition, it appears that unions have tended to concentrate their organizing efforts in indus-

fact that \%org is considerably lower in the South. They did not, however, provide any evidence on whether cross-industry variation in \%oke. explains as much of the cross-industry variation in nomunion wage differentials in the South as if does in the rest of the country. tries with high product market concentration ratios, that is, in industries that have a greater ability to pay high wages. In neither of these cases would the presumed positive relationship between the percent organized and nonunion wages reflect a cathisal effect of the percent organized.

\section{The Data}

We estimate nonumion imdustry wage differentials from log wage regressions estimated for each year using the outgoing rotation group annual files of the CPS for 1983-89 and the May files for 1979-81, to Regressions were estimated separately by race and sex, effectively making all variables interactive with race and sex. Other variables included in the individual-level wage regressions were industry dummy variables; nine one-digit occupation dummy variables (with a bridge between the 1970 and 1980 SOC codes); linear and quadratic schooling; linear and quadratic potential experience; dummy variables for four regions; the unemployment rate in the SMSA or (for non-SMSA residents) in the rest of the state; dummy variables for three SMSA sizes; and dummy variables for married (spouse present) and overtime (based on usual hours worked). All spccifications also include a union status (membership) dummy variable, and a full set of interac. tions of all variables, including the industry dummy variables, with the union stams dummy variable. "To focus on competitive market effects of union wages, we exclude government workers from our sample. Ir addition, to focus on workers for whom threat effects are more likely to matier, we exclude managers, professionals, and the self-employed. The coefficients of the noninteracted industry dummy variable

\footnotetext{
"The individual-level regressions are common $\mathrm{i}$ the literature, so the results are not reported in the paper. Results are available from the authors o request.

11 1982 is omitted because no data were collecte on union membership that year. The definition union membership in the CPS changed slighely ow the years; Hirsch and Neufeld $(1987)$ provide detail
} 
estimate the nonumion industry wage differentials. We estimated the wage differentials for the entire sample by weighting (by industry and nomunion employment) the coefficients estimated from separate regressions by race and gender. ${ }^{\text {th }}$

Our meastre of the percent organized is constructed from the same C.PS data. The first panel of the appendix table provides summary statistics for the inclustry data set, reporting mean levels and the 1973-89 changes for nonunion industry wage differentials and the percent organized, by industry and overall. The data confirm the well-known decline in the percent organized, especially in the industrial sector (for example, Linneman, et al. 1990). The table also suggests that a panel data analysis might show a relationship between the percent organized and the nonunion industry wage differential quite different from that shown by a cross-sectional analysis. While columns (1) and (2) indicate that industries with high \%ORG also have high $w^{n u}$, columns (3) and (4) indicate that, over all industries, \%org and $w^{\text {thi }}$ moved in oppo-

\footnotetext{
Industry wage differentials are estimated relative to services. This raises the problem that estimates of equation (1) could be sensitive to the omitted industry in the "first-stage" individual-level wage regressions from which the wage differentials in equation (1) are estimated. To circumvent this potential problem, we include year dummy variables in equation (1). This removes the influence of the omitted industry, because the common trend across industries owing to the choice of the omitted industry is captured in the year effects. The same issue arises with respect to city wage differentials.

To see how including vear effects solves the problem, suppose that in the first-stage, cross-sectional regression we include dummy variables for each industry, omitting the constant, and estimate their coefficients for each vear $b_{1 y}, b_{1,}, \ldots, b_{A}$, where $K$ is the number of industries. The second-stage regression is then $b_{u}=X_{\gamma} \gamma+\gamma \delta+\varepsilon_{u}, i=1, \ldots, K, t=1, \ldots, T$, where $Y_{i}$ is a set of vear dummy variables. We can transform the estimated nommion wage differentials, for example defining them relative to services (or relative to an average nomunion wage differential across all workers). as in $\left(b_{n}-b_{k+}\right)=X_{n} \gamma+Y \delta+\varepsilon_{u i}$. Since $b_{k}$ taries only by vear, the effect of subtracting it from the dependent variable is simply to change the estimated coefficients of the vear dumm variables, and the estimates of $y$ are maffecred.
}

site directions over the sample period, and some of the industries with the largest declines in \%org had the sharpest increases in $w^{m \cdot 1} \cdot 13$

\section{Empirical Results}

In Table 1 we report resuits from regression estimates of equation (1). In all cases, we report WLS estimates that weight by the inverse of the variance of the OLS residuals, with the variance estimated separately for each industry, pre-and post-1983. These variances may difter by industry because of different numbers of workers in each industry from which $w^{m i n}$ is estimated. They may also differ pre-and post-1983 because, beginning in 1983, we use the outgoing rotation group files and hence have more wage observations. We could weight explicitly by the cell sizes used to estimate $w^{n u}$ in each industry and year; our approach allows for other sources of heteroscedasticity by industry for these two periods. ${ }^{14}$

Estimation without fixed industry effects, in row (1), indicates a statistically significant positive effect of the percent organized on the nonunion wage, consistent with threat effects outweighing crowding effects, and paralleling much of the existing cross-sectional evidence. When fixed industry effects are added in row (2) the estimated coefficient of \%org becomes negative, and is significant with a t-statistic exceeding four. The negative effect of \%orG is the opposite of the effect predicted by the threat model, but is consistent with the crowding model. That model states that a decrease in \%ors causes the nonunion industry wage differential, $w^{m n}$, to rise. To interpret the magnitude of the estimated coefficient of \%oRc, consider a 14 percentage point decline in \%org, which is the average change for our sample pe-

${ }^{13}$ In contrast to the regression estimates discussed below, the nomunion wage differentials in this table may be sensitive to the reference industry with respect to which these differentials are estimated.

${ }^{1}$ For all specifications, results were very similar using either unweighted estimates or estimates weighted by cell sizes. 
Table l. Industry Nonunion Wage Regressions Excluding

Managers and Professionals, 1973-81 and 1983-89.

(Dependent Variable: Nonunion Industry Wage Differential) a

\begin{tabular}{|c|c|c|c|c|c|}
\hline Regressime & $\begin{array}{l}\text { Perient } \\
\text { Corganizeal }\end{array}$ & $\begin{array}{l}\text { Output } \\
\text { Worket }\end{array}$ & $\begin{array}{l}\text { G.VP } \\
\text { Share }\end{array}$ & Adj. $R^{2}$ & Estimntor/Sfrectifitalmu \\
\hline (1) & $\frac{234}{(103)}$ & - & - & .52 & WLS. fixed vear efterts \\
\hline$(2)$ & $\begin{array}{l}-.17 \\
(.04)\end{array}$ & - & - & .99 & WLS, fixed vear and indosiog elleers \\
\hline (3) & $\begin{array}{l}-.17 \\
(.04)\end{array}$ & $\begin{array}{l}.16 \\
(.25)\end{array}$ & - & .98 & Same as $(2)$ \\
\hline$(4)^{6}$ & $\frac{-.12}{(.05)}$ & - & $\begin{array}{l}-.60) \\
(.31)\end{array}$ & .99 & Sane as (2) \\
\hline (5) & $\begin{array}{l}-.19 \\
(.09)\end{array}$ & - & - & .48 & $\begin{array}{l}\text { WLS, fixed year effects, onc-year } \\
\text { differences, omit } 197:\end{array}$ \\
\hline (6) & $\begin{array}{l}-.15 \\
(.05)\end{array}$ & - & - & .63 & $\begin{array}{l}\text { WLS, fixed vear effects, five-vear } \\
\text { differences, omit } 1973-77\end{array}$ \\
\hline (7) & $\begin{array}{l}-.16 \\
(.05)\end{array}$ & - & - & - & $\begin{array}{l}\text { Same as (2), instrument for pricent } \\
\text { organized with ofte-year litg. omit } \\
1973\end{array}$ \\
\hline (8) & $\begin{array}{l}-.65 \\
(.20)\end{array}$ & - & - & - & $\begin{array}{l}\text { Same as (2), insument for percent } \\
\text { organized with NI.RB wariables }\end{array}$ \\
\hline \multicolumn{6}{|l|}{$(9)^{\prime}$} \\
\hline Manufacturing & $\begin{array}{l}-.14 \\
(.04)\end{array}$ & - & - & .99 & Same as (2) \\
\hline Nonmanufacturing & -.28 & & & & \\
\hline \multicolumn{6}{|l|}{$(10)^{c}$} \\
\hline Industrial & $\begin{array}{l}-.17 \\
(.05)\end{array}$ & - & - & .99 & Same as (2) \\
\hline Nonindustrial & $\begin{array}{c}-17 \\
(, 09)\end{array}$ & & & & \\
\hline
\end{tabular}

Standard errors are reported in parentheses. Wi.S estimation allows a separate residual variance for each industry, for the period before 1983 , and for 1983 and after. There are 144 observations except where utherwise, noted.

"The standard deviation of the GNP share variable is .004.

A separate percent organized variable is defined for each subgroup of industries:all other coefficicnts are constritined to be the same for all industries.

Source: Authors computations based on Current Population Surveys, 1973-89.

riod. The coefficient of -0.17 , in the context of this decline in \%org, translates into a $2.4 \%$ increase in $w^{m \text {. }}$.

The remainder of the table reports results from numerous specification analyses of the estimated relationship between the percent organized and nonunion industry wage differentials, exploring possible omitted-variable and endogeneity biases, differences across subgroups of industries, and alternative estimation procedures. First, as a crude means of controlling for changes in labor productivity that might affect non- union wages, in row (3) we add a control for labor productivity in eacls industry. This is computed as the ratio of the current dollas value of GDP (deflated by the GDP implicit price deflator) originating in each industry to full-time equivalent employment in the industry. ${ }^{15}$ Of course, changes in labor productivity should affect nonumion industry wage differentials only if the changes

\footnotetext{
industry-specific price deflators are avalable beginning only in 1977 .
} 
reflect variation in factor productivity, rather than variation in labor quality that is captured in the variables included in the first-stage wage regressions from which the wage differentials are estimated. The estimated coefficient of the labor productivity variable is positive, as we would expect if productivits changesare not entirely driven by changes in the measured quality of labor. However. the estimate is insignificant, and its inclusion dees not affect the estimated cocfficient of \%orG.

Second, in row (4) we add a variable measuring changes in the share of GNP contributed by each industry, to attempt to control for biases induced by industry-specific demand shocks. ${ }^{16}$ To capture indusury-specific demand shocks, this variable is calculated as the residual from a regression estimated for each industry of the GNP share of output produced by the industry on an intercept, the aggregate civilian unemployment rate, and a post-1976 dummy variable to capture the change in accounting methods used in the GNP data reported in the Survey of Current Business. ${ }^{17}$ The estimated coefficient of \%orG declines in absolute value but remains statistically significant, and the estimated coefficient of the GNP variable is negative, contrary to expectations.

The estimates in rows (1)-(4) assume fixed industry effects throughout the sample period. While there is some evidence that nonunion industry wage differentials are very stable (Krueger and Summers 1988), if the unobserved industry effects are not completely fixed, this assumption may bias the results. Thus, rows (5) and (6) report results using differenced data with the differences computed over, alternatively, a short (one-year) and long (five-year) inter-

\footnotetext{
th For example, if nonunion wages are more flexible than union wages, and hence union employment is morc variable than non union employment, a downward industry demand shock will result in a decrease in $w^{m i}$ and a decrease in Morci. In this case such shocks bias the estimated coefficient of \%orG upwitrd

These data do not distinguish between wholesale and retail trade.
}

val. Fvidence of similar effects in the short and long differenced estimates would bolster the assumption of fixed industry effects. In row (5), the first-difference estimate of the coefficient of \%ORG is -.19 , and is statistically significant. The results are similat using a five-year difference; in row (6), the estimated coefficient of \%ore is -15 , and is also statistically significant.

Next.althmughercentorganized is used as an independent variable throughout the literature testing the threat and crowding models, it is potentially endogenous because, for example, increases in nonuniom wages may lead to employment declines in the nonunion sector, creating a positive bias in the estimate of $\beta$ in equation (1). is In row (7). we address this question by instrumenting for the percent organized with its lagged value. Compared with the corresponding specification in row (2), the estimated coefficient is essentially unchanged. Second, we instrument for \%org with measures of union organizing activity or management opposition to this activity at the one-digit industry level, taken from National Labor Relations Board (NLRB) Annual Reports. We use two elections variables, the percentage of NLRB representation elections won by unions, and the number of representation elections per worker in the industry, as well as the number of unfair labor practice claims against employers; the latter two variables are standardized by industry employment. These variables seem likely to affect the probability of unionization, but at the same time to be "one step removed" from simple employment adjustments to wages that may make the percent organized endogenous. The results, reported in row ( 8 ), indicate a stronger negative relationship between the percent organized and the nomunion industry wage differential, although the estimate is less precise.

Rows (9) and (10) explore the robustness of the results for subgroups of indus-

Inchezum and Garen (1993) considered lowe endogeneity of the percent organized in tegressions for union wages. 
tries, in particular manufacturing versus nonmanufacturing, and industrial versus nonindustrial. ${ }^{19}$ The specification from row (2) is augmented to allow the coefficient of Fone to differ across these industry subgroups. As the results indicate, the estimated coefficients of \%orG are negative and significant for all subgroups. ${ }^{20}$

Overall, the results reported in Table 1 indicate that union threat effects are not the predominant union effect on nonunion wage differentials at the industry level. In particular, the results indicate a robust negative relationship between changes in the percent organized and changes in the nonunion industry wage differential. These results suggest that crowding effects are more important than threat effects.

An issue that is worth addressing is whether the negative estimated effect of \%oks in the within-industry regressions actually reflects crowding. As noted above, the crowding model assumes that an increase in the percent organized generates lower nonunion wages because \%orG is a proxy for higher union wages. However, it is the increase in the union wage premium that triggers the crowding effect. If \%orG and union wage premia are in fact negatively correlated, our results may not reflect crowding. However, confirming the view of \%org as a proxy for union wages, we find a positive correlation of 0.13 between \%ORG and the industry union premium, after partialling out fixed industry and year effects.

It is still possible, however, that the negative sign on the percent organized is due to some effect other than the crowding effect. Although the evidence does not point toward threat effects as the predominam

The industrial group includes construction, mining, durables manulacturing, nondurables manufacturing, and TCPU.

"We also explored the sensitivity of the resulis by reestimating the specification in row (2) dropping one industry at a time. The estimated coefficients of \%orc ranged from -.05 to -.23 , averaging -.17 , and the t-statistics ranged from 1.2 to 4.9 . The relatively large range of the coefficient estimates is to be expected given the relatively small number of indusiries. union effect at the industry level, there are possible explanations besides the crowding effect. Below, we develop an alternative hypothesis based on complementarity between union labor and some nonunion labor. Like the crowding hypothesis, the "complements hypothesis" explains the negative coefficient on \%org in the industry-level results, But it also explains such negative intra-industry effects across occupations, which are difficult to reconcile with the crowding model.

\section{Union Effects on Nonunion Wages at the City Level}

Next, we examine union effects on nonunion city wage differentials, rather than nonunion industry wage differentials. A number of papers on the threat and crowding models, cited earlier, look at union effects on non union wages within Standard Metropolitan Statistical Areas (SMSAs).

One might expect labor supply shifts from the union sector to the nomunion sector to be more prevalent within cities than within industries. ${ }^{21}$ Evidence from the January 1988 Displaced Workers Survey in the CPS (Herz 1991) supports this presumption. The survey shows that roughly one-half of the workers displaced between 1983 and 1988 , and reemployed by 1988 , took a job in a new industry (with the exception of mining, for which the figure was one-fourth), while only about one-fifth of such workers took a job in a new city or county. All else the same, this would lead us to expect more evidence of crowding at the city level.

But all else may not be the same, since it is also possible that threat effects are stronger within cites than within industries. Many unions, particularly those in the service-producing sector, have powerful local unions that organize at the city level. Success in organizing workers in one of the service-producing industries may increase the likelihoud or the threat that other ser-

\footnotetext{
"Holzer (1982) made this argument, on a priori gronnds, in focusing on union spillover effects within SMSAs.
} 
vice-producing sectors will become unionized in the same local geographical area. Also, as shown in the appendix table, column (4), industrial unions declined sharply over our sample period, while unions in at least some of the service-producing sectors held their own.

\section{Past Research on Union Effects on Nonunion Wages at the City Level}

As is the case in the existing literature testing the alternative models at the industry level, the existing evidence at the SMSA level comes from cross-sectional regressions. Some of this evidence tends to support the threat model, at least for white male workers. Holzer (1982) found that the percent organized was positively associated with nonunion wages for young white men, but negatively associated with nonunion wages for young black men. These findings parallel Kahn's $(1978,1980)$ results from regressions between the percent organized among all workers in an SMSA and nonunion wages in relatively unorganized industries. ${ }^{22}$ Similarly, Freeman and Medoff (1984) reported an overall positive relationship across cities, in regressions pooling multiple years (but not including fixed city effects). Evidence providing little support for threat effects at the city level was reported by Hirsch and Neufeld (1987). They controlled for the percent organized in the industry and the SMSA in regressions for nonunion wages of individuals. Their results support the threat effect at the industry level, but indicate that SMSA union density has little impact.

Following the sanc kind of procedure we used in our industry-level analysis, we improve on the existing SMSA-level research by estimating the relative strength of the threat and crowding effects in a panel data framework that removes biases arising from unmeasured, fixed city characteristics. Just

"One might wonder whether the negative effects of the percent organized on the wages of younger, minority nonumion workers reflect crowding, since union workers maty be more likely to be substitutes for older, skilled workers. The complements hypothesis discussed below mav herter explain these findings. as biases may arise at the industry level because unions may target firms in relatively high-wage industries for their organizing efforts, biases may arise at the city level because unions may target firms in high-wage cities.

\section{The Data}

The data set used for this analysis is similar to that used at the industry level. Our procedure for estimating nonunion city wage differentials is parallel to the procedure we used to estimate nonunion industry wage differentials, using the subset of observations on individuals residing in SMSAs identified in the CPS; 44 SMSAs are identified, for some or all of the sample years. Nonunion wage differentials are estimated for each SMSA, for each year in which the SMSA is identified, resulting in an unbalanced panel for the second-stage analysis. As before, we exclude government workers, managers and professionals, and the self-employed, and estimate the wage regressions separately by race, sex, and year. The specifications also include dummy variables for 26 industries, and interactions of each of these with union status. Finally, the specifications include dummy variables for each city, plus interactions of these dummy variables with union status. The coefficients of the noninteracted city dummy variables estimate the nonumion city wage differentials. For the city-level analysis, in contrast to the industry-level analysis, the NLRB, GNP share, and productivity rariables are unavailable.

The second panel of the appendix table provides summary statistics for the SMSA data set, reporting neatu levels and the 1973-89 changes (for a subset of 39 SMSAs) for nonunion city waye differentials and the percent organized. In contrast to the industrv-level data, where \%oRG and w moved in opposite directions, in the SMSAlevel data \%ORG and $i t^{m}$ move in the same direction over the sample period. ${ }^{23}$ This

${ }^{25}$ The same qualification noted in foomote 13 applies, becatse the nonunion wage differentitls are defined relative to a particular SMSA (New lak ) 
Table 2. City Nomunion Wage Regressions Excluding

Managers and Professionals, 1973-81 and 1983-89.

(Dependent Variable: Nonunion City Wage Differential)a

\begin{tabular}{|c|c|c|c|c|}
\hline Regression & $\begin{array}{l}\text { Perrent } \\
\text { Organized }\end{array}$ & $\begin{array}{l}\text { State and } \\
\text { Leral Percent } \\
\text { Organized }\end{array}$ & $A d j \cdot R^{2}$ & Estimator/Specification \\
\hline (1) & $\begin{array}{c}.08 \\
(.02)\end{array}$ & - & 39 & WLS, fixed year effects \\
\hline (2) & $\begin{array}{l}.10 \\
(.04)\end{array}$ & - & .90 & WLS, fixed year and city effects \\
\hline$(3)^{b}$ & $\begin{array}{l}.11 \\
(.04)\end{array}$ & - & .91 & Same as (2) \\
\hline$(4)^{t}$ & $\begin{array}{l}.11 \\
(.04)\end{array}$ & $\begin{array}{l}-.004 \\
(.007)\end{array}$ & .91 & Same as (2) \\
\hline (5) & $\begin{array}{l}.03 \\
(.03)\end{array}$ & - & .42 & $\begin{array}{l}\text { WLS, fixed year effects, one-year } \\
\text { differences, omit } 1973\end{array}$ \\
\hline (6) & $(.03)$ & - & .56 & $\begin{array}{l}\text { WLS, fixed year effects, five-vear } \\
\text { differences, omit } 1973-77\end{array}$ \\
\hline (7) & $\begin{array}{l}.50 \\
(.21)\end{array}$ & - & - & $\begin{array}{l}\text { Same as (2), instrument for percent } \\
\text { organized with one-year lag, omit } \\
1973\end{array}$ \\
\hline \multicolumn{5}{|l|}{$(8)^{\circ}$} \\
\hline Right-to-Work States & $\begin{array}{l}.14 \\
(.07)\end{array}$ & - & .90 & Same as (2) \\
\hline Non-Right-to-Work States & .09 & & & \\
\hline
\end{tabular}

${ }^{4}$ Standard errors are reported in parentheses. WLS estimation allows a separate residual variance for each city, for the period before 1983, and for 1983 and after. There are 620 observations on the 44 cities identified in the CPS for some or all of the years from 1973 to 1989 , except where otherwise noted.

tOmits 31 observations with no state and local government workers.

A separate percent organized variable is defined for each subgroup of states; all other coefficients are constrained to be the same for all states. Seventeen percent of the observations are in SMSAs primarily in states with right-to-work laws.

Source: Authors' computations based on Current Population Surveys, 1973-89.

foreshadows the regression results that provide evidence of union threat effects predominating at the city level.

\section{Empirical Results}

Table 2 reports regression results for equation (1), estimated at the silst level. The panel data evidence regarding the effect of the percent organized is inconsistent with crowding effects predominating, but instead generally suggests that threat effects predominate. This is shown in row (2) where, with city effects included, the estimated coefficient of \%org is positive and significant. In contrast to the industrylevel estimates, the estimated coefficien is not very different if we omit the fixed city effects, as row (1) shows. The estimated magnitude in row (2) implies that the effect of a 15 percentage point decline in the percent organized (the overall average in the appendix table) is to reduce the nonunion city wage differential by $1.5 \%$.

We nextadd the percentage of state and local workers unionized to the equation, to arratlye union threat and croweling effects stemming from public-sector unions, wather than just private-sector tmions. For some observations, the public-sector percent organized cannot be calculated, because there are no state and local workers in the sample. Thus, row (3) first repeats the previous specification for the subsample for which this percent organized can be calculated. The estimates are virtually unchanged. Row 
(4) shows that the estimated coefficient of the percent organized among public-sector workers is small and insignificant, and that the inclusion of this variable has no impact on the estimated coefficient of the private-sector percent organized.

In rows (5) and (6), to assess the sensitivity of the results to the fixed-effects assumption, we report the onc-year and five-year differenced estimates rather than withingroup estimates. In both rows, the estimated coefficient of \%ORG is still positive, although no longer statistically significant, implying that the inference that threat effects predominate at the city level is somewhat fragile.

Row (7) reports results instrumenting for \%ORG with its lagged value. The instrumental variables procedure again results in a sizable increase in the standard error of the estimated coefficient of \%org. But the estimate remains positive and statistically significant. ${ }^{24}$

Finally, we consider results disaggregated by states (in which cities are located) that did and did not have right-to-work laws. ${ }^{25}$ The city-level results to this point generally suggest that threat effects predominate. If right-to-work laws reduce the threat of unionization, we might expect to find less evidence of threat offects in jurisdictions with right-to-work laws. On the other hand, the results could go the other way because

\footnotetext{
${ }^{24}$ We also explored the sensitivity of the results by reestimating the spectication in fow (2) dropping one ciry at a time. The estimated coefficients of :oore; ranged from on to $1 \%$, and the t-statistics ranged from 2.4 in 3.9

25 Informatuon wh state right-fo-work laws was abtamed from the Xational Right to Wotk Commitede.

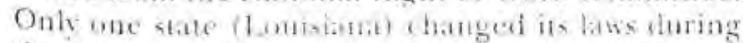
the sample pertod. 'There is some amavordable slippage in identifing individuals in SMS to-work laws, becante some of the SMSAsasdefined in the CPS smaddle more than one state. This is a problem for the Withingun, D.C. SMSA. since Virginia (but not D.C. of Narvland) has a right-to-work law, and for the Kinsas City SMSA, since Kinsas (but not Missouri) has a right-10-work law. Even if we identify workers in such SMSAs by the state in which they reside, we have 110 information on the state in which they work.
}

the same percentage of the work force unionized in a right-to-work state as in a non-right-to-work state may represent a higher proportion of unionized establishments in the former, since such establishments are more likely to have nonunion workers. The results, reported in row (8), indicate that threat effects predominate in both types of jurisdictions, and if anything appear to be stronger in right-to-work states.

Thus, ovcrall, the city-level results are consistent with threat effects, rather than crowding effects, being the predominant union effect on nonunion wages. This result, in conjunction with the industrylevel crowding results in Table 1 , suggests that within a city the threat effect is stronger, and the crowding effect is weaker, than at the industry level, at least insofar as the threat effect is captured by the percent organized. This pattern supports the anecdotal evidence that locally organized unions in the service-producing sectors create more of a threat effect, within a geographical area, than nationally organized industrial unions create within an industry, at least within our sample period (when industrial unions were in decline).

\section{Union Effects on Nonunion Wages Within and Across Occupations}

Our last analysis focuses on union effects on nonunion wages across occupations within an industry. This analysis provides cvidence on an altemative to the crowding explanation of the negative effect of the percent organized on nonunion industry wage differentials. This alternative explanation is based on the complementarity of union and at least some nununion habot. Complementarity between anton and nonunion labor can atse if nomunion workers are employed by firms acting as supplices to or distributors for union firms, or if nonunion workers are employed alongside union workers in the same firm. The complements hypothesis does not require the absence of a nonumion sector that competes directly with the union sector, but only that scale effects in the nonunion complements sector are stronger than ef- 
fects in the nonunion substitute sector, ${ }^{26}$

If this condition is met, then an increase in the percent organized-which, as discussed above, is likely to be associated with a higher union wage-causes a decline in output, entailing a decline in demand for complementary nonunion labor and, hence, a decline in the nonunion wage. Changes in the percent organized in the complements model would thus generate the same predictions as in the crowding model. ${ }^{27}$ However, as the preceding discussion makes clear, the complements hypothesis focuses on demand shifts caused by changes in the percent organized, in contrast to the focus of the crowding hypothesis on supply shifts.

The fact that the crowding and complements hypotheses can both explain the negative effect of \%ORG in the industrylevel equations makes it impossible to differentiate them at this level. However, the alternative hypotheses do have different predictions for union effects on nonunion wages across occupations. If occupations are sufficiently different in skill or training requirements, then labor supply crowding effects cannot occur. Thus, cross-occupation effects isolate effects of the percent organized on wage differentials of nonunion workers whose wages are unlikely to be affected by supply shifts out of the union sector. A finding of negative effects of the percent organized on nonunion industry

\footnotetext{
2tiscale effects would have to drive the complenentarity, since it secms implausible that the partial elasticities of substitution between these differentupes of labor are tegative (Hamernesh 1993).

${ }^{27}$ On the other hand. the models could in principle be distinguished by the thece of the percent organized on nommion employment, which should be positive in the coowding model, and (most likely) negative in the complements model. We are not aware of any evidence that addresses this question at the industry level. One problem is that the percent organized is endogenous with respect to nonunion employment. The effects of the percent organized on nonunion employment have been addressed at the SMSA level by Holzer (1982) and at the aggregate level by Pencavel and Hartsog (1984). In related work, Kahn (1980) and Kahn and Morimune (1979) examined the effects of the percent organized on hours and on unemployment.
}

wage differentials across occupations would suggest that complementarity between union and nonunion workers may be an important factor in the aggregate industrylevel results. In contrast, a finding of negative effects within occupations, but not across occupations, would suggest that crowding effects better explain the industry-level results of Table 1.

\section{Past Research}

There is litule existing evidence on withinand across-occupation effects of the percent organized on nonunion wages. Freeman (1981) found that white-collar workers had higher fringes in organized plants than in unorganized plants. Mitchell (1980) studied time-series evidence on changes in clerical pay in highly unionized cities, and concluded that employers did not pass union wage gains on to clerical workers. Hirsch and Neufeld (1987) reported separate cross-sectional estimates (for many years) of the relationship between the percent organized in the industry and nonunion wages for production workers in manufacturing, production workers in nonmanufacturing, and nonproduction workers. The estimated coefficients of the percent organized were positive and generally significant. But they reported no crossoccupation effects, nor pooled results including fixed industry effects.

\section{The Data}

To add another dimension to the crossoccupation analysis, in this section we add information on nonunion industry wage differentials and the percent organized among managers and professionals, in addition to blue-collar and other white-collar workers." This occupational disaggregation seems likely to at least partially satisfy the requirements of complementarity be-

\footnotetext{
${ }^{2 *}$ The percent organized is non-negligible among managers and professionals. Across industries, the average percent organized for our sample is 9.6 . versus $11.8 \%$ for other white-collar workersand $34.6 \%$ for blue-collar workers.
} 
tween union and nonumion labor, and "immunity" from supply shifts. Clearly, bluecollar and either managerial/professional or other white-collar workers may be production complements. Furthermore, workers are relatively unlikely to move among these sectors, especially between blue-collar and managerial/professional occupations. Unpublished tables provided by the Bureau of Labor Statistics vield the following figures for workers displaced in 1983 and reemployed in 1988. Seventy-one percent of those displaced from blue-collar jobs were reemployed in blue-collar jobs, while $7 \%$ were reemploved in managerial/ professional jobs, and $9 \%$ were reemployed in other white-collar jobs. Fifty-nine percent of those displaced from managerial/ professional jobs were reemployed in managerial/professional jobs, while $7 \%$ were reemployed in blue-collar jobs, and $28 \%$ were reemployed in other white-collar jobs. Finally, $68 \%$ of those displaced from other white-collar jobs were remployed in similar jobs, while $11 \%$ were reemployed in blue-collar jobs, and $14 \%$ were reemployed in managerial/professional jobs. (The remaining jobs held by reemployed workers are in service occupations.)

The within-industry nonunion differentials are estimated from the same log wage regressions used for the industry-level analysis. The only difference is that all variables are interacted with dummy variables for white-collar workers, and for managers and professionals among white-collar workers (who are now included). Service workers are omited from the analysis.

\section{Effects Within and Across Occupations}

Tables reportsestimates of the effects of the percent organized hoth within and across occupations. Effects of the percent organized on wage differentials of nonunion blue-collar workers are reported in rows (1)-(4), for managers and profession-

\footnotetext{
The third panel of the appendix reports some descriptive statistics lon the imfustry data distggregated by occupation.
}

als in rows $(5)-(8)$, and for other whitecollar workers in rows $(9)-(12)$. As before, we include estimates incorporating fixed industry (and year) effects, and report WLS estimates allowing for industry-specific heteroscedasticity that can vary pre- and post-1983.

Turning first to the within-occupation effects, in row (1) we include only the effect of \% ORG BC (percent of blue-collar workers in an industry who are mionized) on the wage differentials of nonunion bluc-collar workers. The within-occupation effect of percent organized is negative and significant. An increase of one percentage point in \%org BC would result in a $0.3 \%$ decrease in nonunion, blue-collar wages. In row (5) we include only the effect of \% ORG MP (percent of managers and professionals in an industry who are unionized) on the wage differentials of nonunion managers and professionals. The estimated within-occupation effect is positive and marginally significant. In row (9) we report a similar specification for other white-collar workers, and in this case the elfect of \%orc wo is positive and significant, with the estimate implying that a decrease of one percentage point in \%orG wc would result in a $0.21 \%$ decrease in nonunion wages of other whitecollar workers. These results support the threat effect in the white-collar and management and professional market, and the crowding effect in the bluc-collar narket. ${ }^{30}$

It is interesting that the threat effect is found in the white-collar and management and professional market, where the percent organized is low but has held relatively

\footnotetext{
sof course it is possible that the exe is a complements effee within the bluedellar setol, although

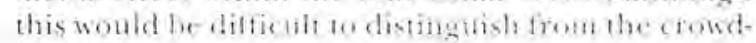
ing elfeet,

In estimates wihout fixed indusery plfects. the estimated own-oceupation effeces of the percent organized were positive for both blute-collar and other white-collar workers (aldhough not for managerial, professional workers). This parallels the eross-sectional evidence reported in Hisseh and Neuteld (1987), in which there is it positive relationship between nonmion wages and the percent organized in the industry for botls produstion workers and nomproduction workers.
} 
Table 3. Across-Occupation, Indusiry Nonunion Wage Regressions, 1973-81 and 1983-89.

(Dependent Variable: Blue-Collar, Managerial/Professional. and Other White-Collar Nommion Industry Wage Differentials)a

\begin{tabular}{|c|c|c|c|c|c|}
\hline \multirow[b]{2}{*}{ Regression } & \multicolumn{3}{|c|}{ Percent Organized } & \multirow[b]{2}{*}{${ }_{R^{2}}^{A d j}$} & \multirow[b]{2}{*}{ Estimator/Specificution } \\
\hline & Bhue-Collar & $\begin{array}{l}\text { Managers/ } \\
\text { Professionals }\end{array}$ & $\begin{array}{c}\text { Ocher } \\
\text { White-Collar }\end{array}$ & & \\
\hline
\end{tabular}

A. Results for Blue-Collar Nonumion Industry Wage Differential

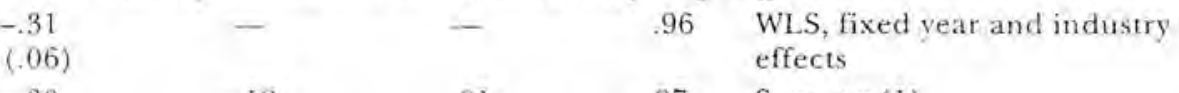

$\begin{array}{ccc}(.06) & & \\ -.30 & -12 & -01 \\ (.06) & (.06) & (.07) \\ -.29 & -.04 & -.03 \\ (.07) & (.07) & (.07) \\ -.18 & -.08 & -.01 \\ (.07) & (.05) & (.08)\end{array}$

.97 Same as (1)

$-103 \quad .51$

.51 WLS, fixed ycar effects, one-year differences, omit 1973

B. Results for Manager/Professional Nonunion Industry Wage Differential

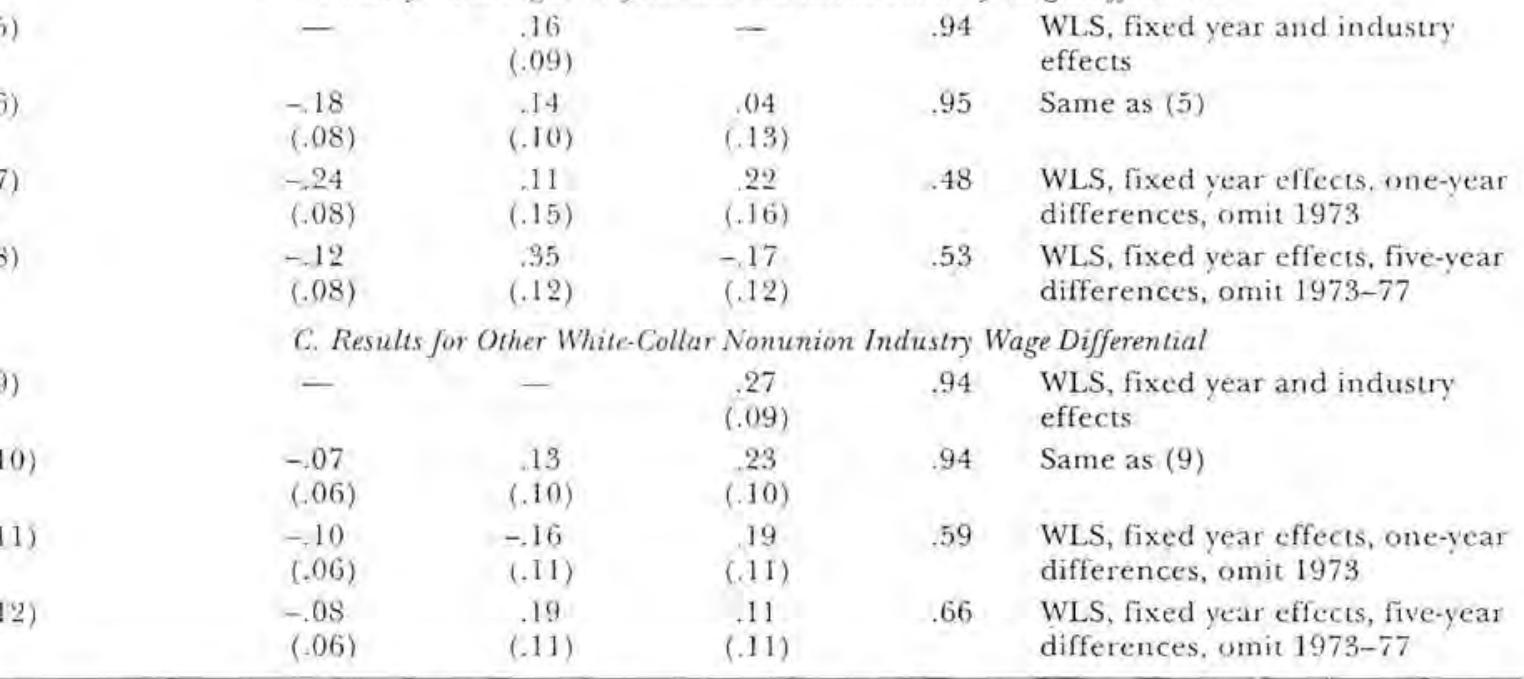

"Standard errors are reported in parentieses. There are 144 observations. See footnotes to Table 1 for additional details.

Simere: Authors computations based on Current Population Surveys, 1973-89.

stable, whereas the crowding effect is found in the blue-collar market, where the percentorganized has decreased shat ply. Large declines in the percent organized among bluc-collar workers over the $1970 \mathrm{~s}$ and 1980 s, averaging, in otm data, 1.1 pereentage points per year, may have implied small threat effects, despite a relatively high pereene organized, compared with manage$\mathrm{rial} / \mathrm{professional}$ and other white-collar workers, for whom the percent organized was essentially flat in this period (see the third panel of the appendix table). Coupled with the results in Table 3 , these figures suggest that threat effects may depend on the change in and not just the level of the percent organized.

The other rows of Table 3 show crossoccupation effects. In the specilication for the ronunion industry wage differential for each occupation, the pereentorganized in each of the three occupations is included. In these specifications, negative cross-occupation effects are consistent with complements effects predominating. Rows (2), (6), and (10) report within-groupestimates. In the regression for the blue-collar industry wage differential (row 2), the estimated coefficient of \%ORG MP is negative and significant. In the regressions for the white- 
collar and management/professional industry wage differentials (rows 6 and 10), the estimated coefficients of \%orG BC are negative, although significant only in the regression for managers and professionals. Thus, these results appear to provide evidence of a complementary relationship between blue-collar and management/professional workers.

The other rows report similar estimates using one- and five-year differences, instead of within-group estimates. The evidence suggesting complementaritvbetween blue-collar and management/professional workers is similar in these alternative estimates, although statistically weaker for the five-year differences, which may not be surprising given that fewer observations are used.

In our view, the results for the crossoccupation effects provide evidence that negative union effects on nonunion industry wages are partly driven by complementarity. The reason is that the negative overall industry-level effects appear to come from negative within- and across-occupation effects. Since the cross-occupation effects cannot be coming from workers displaced from the union sector, and hence are not coming about via supply shifts, an explanation of the negative relationship between the percent organized and nonunion wages other than the crowding model may also be nceded.

\section{Conclusions}

We have estimated the relative strength of union threat and crowding effects by investigating (1) within-industry, (2) withinSMSA, and (3) within-industry, across-occupation effects of changes in the pereent organized on changes in nonumion wages. The existing literature on threat and crowding effects uses cross-sectional data that isolate these effects across industries or SMSAs at a point in time. These results tend to support the threat model, especially at the industry level. A major weakness of these results, however, is that they are subject to biases from unmeasured industry or city characteristics. For example, industries that have high nonumion wage differentials may be industries with industry rents that made them ripe for unionization. A key innovation in this paper is to use a panel data set of cross-sectional observalions for the period 1973 to 1989. This research design enables us to test for threat and crowding effects within industries and cities across time. Using a fixed-effects estimator, we attempt to avoid the omittedvariable problem inherent in the cross-sectional results.

Contrary to the results of cross-sectional studies, ou industry-level results reject the conclusion that threat effects are the predominant union effect on nonunion wages. Although union threats may have been operating at the industry level, they appear to have been overwhelmed by other forces. Within-industry increases in the percent organized were associated with decreases in nonunion industry wage differentials, This result is consistent with crowding effects predominating. At the city level, however, our regression results indicate that union threat effects predominate. The contrasting results at the industry and city levels are consistent with anecdotal evidence that locally organized unions in the serviceproducing sectors create more of a threat effect within a geographical area than nationally organized industrial unions create within an industry. Such a pattern seems especially plausible within our sample period, during which industrial unions were in decline.

Another innovation of this paper is its examination of occupational data within industrics. We find negative effects of the percent organized among blue-collar workers on nonunion industry wage lifferentials of managers and professionals, and negative effects of the percent organized among managers and professionals on nonumion industry wage differentials of blue-collar workers. These results suggest that the negative effect of the percent organized on nonunion wages at the industry level may reflect not solely crowding effects, but complementaritics belween union and nomunion labor as well. 


\section{APPENDIX}

Descriptive Statistics"

\begin{tabular}{|c|c|c|c|c|}
\hline & \multicolumn{2}{|c|}{ Levels } & \multicolumn{2}{|c|}{1973 tw 1989 Changes } \\
\hline & $\begin{array}{l}\text { Nonunion } \\
\text { Wage Differential } \\
\text { (I) }\end{array}$ & $\begin{array}{l}\text { Percent } \\
\text { Organized } \\
\text { (2) }\end{array}$ & $\begin{array}{c}\text { Nonunion } \\
\text { Wage Differential } \\
\text { (3) }\end{array}$ & $\begin{array}{c}\text { Percent } \\
\text { Organized } \\
\text { (-4) }\end{array}$ \\
\hline \multicolumn{5}{|l|}{ Industry Data: } \\
\hline All Industries & $\begin{array}{l}15 \\
(.12)\end{array}$ & $\begin{array}{l}.27 \\
(.16)\end{array}$ & $\begin{array}{l}.05 \\
(.05)\end{array}$ & $\begin{array}{l}-.14 \\
(.10)\end{array}$ \\
\hline Construction & $\begin{array}{l}.18 \\
(.03)\end{array}$ & $\begin{array}{l}.35 \\
(.07)\end{array}$ & .08 & -.18 \\
\hline Mining & $\begin{array}{c}36 \\
(.06)\end{array}$ & $\begin{array}{c}.40 \\
(.11)\end{array}$ & .18 & -.31 \\
\hline Manufacturing, Durables & $\begin{array}{l}.18 \\
(.02)\end{array}$ & $\begin{array}{l}.40 \\
(.08)\end{array}$ & .04 & -.21 \\
\hline Manufacturing, Nondurables & $\begin{array}{l}.13 \\
(.02)\end{array}$ & $\begin{array}{l}.32 \\
(.06)\end{array}$ & .05 & -.16 \\
\hline TCPU & $\begin{array}{l}.23 \\
(.03)\end{array}$ & $\begin{array}{c}.52 \\
(.07)\end{array}$ & .02 & -.18 \\
\hline FIRE. & $\begin{array}{l}.13 \\
(.03)\end{array}$ & $\begin{array}{l}.05 \\
(.01)\end{array}$ & .07 & -.02 \\
\hline Wholesale & $\begin{array}{l}.16 \\
(.01)\end{array}$ & $\begin{array}{l}.13 \\
(.04)\end{array}$ & .03 & -.10 \\
\hline Retail & $\begin{array}{l}-.06 \\
(.01)\end{array}$ & $\begin{array}{l}.12 \\
(.03)\end{array}$ & .004 & -.09 \\
\hline Services & - & $\begin{array}{l}.16 \\
(.01)\end{array}$ & - &,- 01 \\
\hline \multicolumn{5}{|l|}{ City Data: } \\
\hline All Cities & $\begin{array}{l}-05 \\
(.08)\end{array}$ & $\begin{array}{l}.29 \\
(.12)\end{array}$ & $\begin{array}{l}-.04 \\
(.07)\end{array}$ & $\begin{array}{l}-15 \\
(.05)\end{array}$ \\
\hline \multicolumn{5}{|l|}{ Industry Data, by Occupation: } \\
\hline All Industries, Blue-Collar & $\begin{array}{l}.10 \\
(.12)\end{array}$ & $\begin{array}{l}.35 \\
(16)\end{array}$ & $\begin{array}{l}.04 \\
(.04)\end{array}$ & $\begin{array}{l}-17 \\
(.09)\end{array}$ \\
\hline $\begin{array}{l}\text { All Industries, Managers } \\
\text { and Professionals }\end{array}$ & $\begin{array}{l}.29 \\
(12)\end{array}$ & $\begin{array}{l}.10 \\
(.08)\end{array}$ & $\begin{array}{l}-.02 \\
(.05)\end{array}$ & $\begin{array}{l}-, 04 \\
(.07)\end{array}$ \\
\hline All Industries, White-Collar & $\begin{array}{l}.10 \\
(.11)\end{array}$ & $\begin{array}{l}.12 \\
(.11)\end{array}$ & $\begin{array}{l}-.01 \\
(.08)\end{array}$ & $\begin{array}{l}-.04 \\
(.05)\end{array}$ \\
\hline
\end{tabular}

"Standard deviations are reported in parentheses. All estimates in the table are unweighted. Data in each pancl are described in more detail in the corresponding table of regression results. For the city data, wage ptemiums are estimated relative to New York. For the industry-occupation data, they are estimated relative to blue-collow, services.

Whe changes are defined tor the subset of 33 cities with data for all vears.

Sonte: Anthors' compritations based on Current Population Surveys, 1973-89, 


\section{REFERENCES}

Abowd. John. 1989. "The Fflect of Wage Bargains on the Stock Market Value of Firms." American Economic Review, Vol. 79. No. 4 (September), pp. 774800.

Akerlof, George A. 1982. "Labor Contracts as Partial Gift Exchange." Quarterty Journal of Eionomics, Vol. 91, No. 4 (November), pp. 543-69.

Allen, Steven G. 1984. "Unionized Construction Workers Are More Producrive." Quarterly /ournal of Economics, Vol. 99, Vo. 2 (Mas), pp. 251-74.

Bronats, Stephen C., Donald R. Deere, and Joseph S. Tracy. 1993. "Profitabilitv, Union Spillover Effects, and the Efficiency of Union Contracting." Unpublished paper, University of Texis.

Brown, Charles, and James Medolf 1978. "Trade Unions in the Production Process. "Journal of Politi. cal Eomom), Vol s6, No. 3 (June), pp. 355-78.

Brown, James N...and Orley Ashenfeler. 1986. "Testing the Efficiency of Employment Gontracts." Journal of Political Economy. Vol. 94. No. 3 (June), pp. $\mathrm{S} 40-\mathrm{S} 87$.

Chezum, Brian, and fohn E. Garen. 1993. "The Simulaneous Determination of Union Wages and Union Organization: Theery and Fridence." Unpublished paper, St. lawrence University.

Clark, Kim. 19S0. "The Impact of Unionization on Productivicy: A Case Sunly." Industrial and Labor Rulations Rezilew, Vol, 33, No. 4 (July), pp, 45l-69.

Conant, Eaton B. 1959. "Defenses of Nonunion Employers: A Study from Company Sources," Labor Law fournal, Vol. 10, No. 2 (February), pp. 100-109.

Cullen, Donald E. 1956. "The Interindustry Wage Structure, 1899-1950." American Economu Review, Vol. 46, No. 3 (June). pp. 353-69.

Dickens, William T 1986 . Wages, Employment, and the Threat of Collective Action be Workers." Unpublished paper. Liniversity of California-Berkelev.

Dickens, Willian T., and Lawence F. Katz. $1987 \mathrm{a}$. "Inter-Industow Wiage Differences and Industry Characteristics." In kevin lang and Jonathan S.

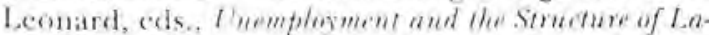
bor Morken. New York: Basil Blackwell. pp. 48-89.

$1987 \mathrm{~b}$ "Inter-Industry Wage Differences and

Theories of Wage Determination." NBER Working Pitper Yo. 22zil

Dickens. William T. and Brian A. Ross, 1984.

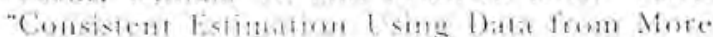

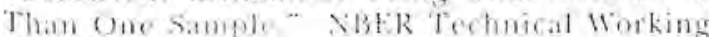
Paper No. 38.

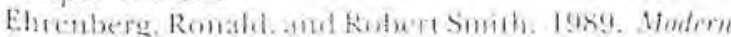

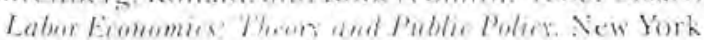
Harper Collins

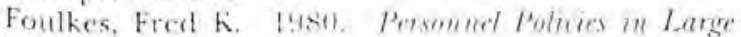
Nonumion Gompanes, Bngleweond Cliffs, N.J: Prentice-Hall.

Freeman, Richard B. 1981. "The Effect of Trade Unionism on Fringe. Bencfits." Iudustrial and Labor Relulions Rerveze. Vol 34, No. 1 (July), pp. 4\$9-509.

Freeman, Richard B. and Vomis M. Klener, 1988. "Emplover Behavior in the Fote al Lnion Organiz. ing Drives." NBER Working Paper No. 2805

Freeman, Richard B., and James L. Medoff, 1981. "The Impact of the Percentage Organized on Union and Nonunion Wages." Revican of Economics and Statisties, Vol. 63, No, 4 (November), pp. 561-72 1984. What Do Unions Do? New York: Basic Books.

Friedman, Milton. 1951. "Some Comments on the Significance of Labor Unions for Economic Polics:" In D. M. Wright, ed., The Impart of the Unim New York: Harcourt, Brace, pp+ 204-34.

Hamermesh, Daniel S. 1993. Labor Demand. Princeton, N.J: Princeton University Press.

Helwege, Jean. 1992. "Sectoral Shiftsand luterindusury Wage Differentials." Journal of Labor Ecomomics, Vol. 10. No. 1 (Januarv). pp. 55-84.

Herz, Diane E. 1990. "Worker Displacement in a Period of Rapid Job Expansion: 1983-87," Monthl Labor Review, May, pp. 21-33.

Hirsch, Barry T., and John 1. Neufeld. 1987. "Nominal and Real Union Wage Differentials and the Effects of Industry and SMSA Density." Journal of Human Resouras, Vol. 22, No. ? (Winter), Pp. 13848.

Holzer, Harry J. 1982. "Unions and the Labor Market Status of White and Minority Youth." Industrial and Labor Relations Revietw, Vol. 35, No. \& (April), pp. $392-405$.

Kahn, Lawrence M. 1978. The Effects of Lnions on the Earnings of Nonunion Workers," Industrial and Labor Relatiuns Review, Vol. 31, No. 2, pp. 205-16. 1979. "Union Strength and Wage Inflation." Industrial Relations, Vol. 18, No. 2 (Spring), pp. 14455.

1980. "Union Spillover Effects on Organized [sic] L.abor Markets." Jouznal of Human hevoures. Vol. 15, No. 1 (Winter), pp. 87-98.

Kahn, Lawrence M., and Kimio Morimune. 1979. "Unions and Emplovment Stability: A Sequential Logit Approach." International Eeonomir Retreso. Vol. 20. No. 1 (February). pp. 217-35.

Keane, Michael P. 1993, "Individual Heterogeneiti and Interindustry Wage Differentials." Joureal of Human Risourres, Vol. 28, No. 1 (Winter). pp. 19.161 .

Fueger. Alin B.. and Lawrence H. Summers. Itso "Efficiency Wages and the Inter-Industre Wage

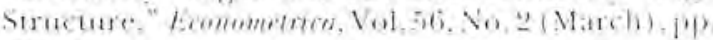
$459-9 \cdot 1$

1987. "Rellections on the lnter-ludustry Wage Stucture, " In Kevin Latrg atmd fonathan S. Leonard. eds., Luemplonment and the Strueture af Labor. Markets. New Jork: Basil Blackwell, pp. 17-17.

Lindbeck, Assat, and Dennis J. Suower. 1988. The Insider-Ontsider Thery of Eimplerment and Lowemplos. ment. Cambridge. Mass: MIT Press.

Linneman, Peter D., Machael L. Wacher, and William 11. Carter. 1990. "Fvaluating the Evidence on Union Emplovment and Wages." Industrul and Labor Refutians Ratera, Vol, 44, No. 1 (October), PP. $34-53$ 
Mincer, Jacob. 1976. "Unemployment Effects of Minimum Wages." Journal of Political Economy, Vol. 84, No. 4. Part 2 (August), pp. S87-S102.

Mitchell, Daniel J.B. 1980. Unions, Wages, and Infla tim. Washington, D.C.: Brookings Institution.

Moltton, Brent R. 1990. "An Illustration of a Pitfall in Estimating the Effects of Aggregate Variables on Micro Units." Revieu of Economics and Statistics, Vol. 72, No. 2 (May), pp. 334-38.

Neminark, David, and Michael L. Wachter. 1993. "Efficiency-Wage/Union Effects on the Nonunion Industry Wage Structure." Procesdings of the FortyFifth Annual Meeting, Industrial Relations Research Association, pp. 151-61.

l'encavel, John, and Catherine Hartsog. 1984. "A Recousideration of the Effects of Unionism on Rela-
Live Wages and Employnent in the United States," Journat of Labor Eionomics, Vol, 2, No. 2 (April), pp. $193-232$.

Podgursky, Michael. 1986. "Wnions, Establishment Size, and Intra-Industry Threat Effects." Industrial and Labor Relations Review, Vol. 39, No.2 (January), pp. 277-84.

Rees, Albert, and George P. Schultz. 1970. Workers and Wages in an Uiban Labor Markf. Chicago, III: University of Chacigo Press.

Reynolds, L.loyd G., Stanley H. Masters, and Collenta H. Moser. 1991. Labor Economics and Labor Relations. Englewood Clifts, N.J.: Prentice Hall.

Rosen, Sherwin, 1969. "Trade Union Power, Threat Effects, and the Extent of Organization." Rezieu of Eeonomic Studies, Vol. 36, No. 2 (April), pp. 185-96. 